\title{
Joint effects of ethnic enclave residence and ambient volatile organic compounds exposure on risk of gestational diabetes mellitus among Asian/Pacific Islander women in the United States
}

Andrew D. Williams ${ }^{1 *}$ (D), Sandie Ha ${ }^{2}$, Edmond Shenassa ${ }^{3}$, Lynne C. Messer ${ }^{4}$, Jenna Kanner ${ }^{5}$ and Pauline Mendola ${ }^{5}$

\begin{abstract}
Background: Asian/Pacific Islander (API) communities in the United States often reside in metropolitan areas with distinct social and environmental attributes. Residence in an ethnic enclave, a socially distinct area, is associated with lower gestational diabetes mellitus (GDM) risk, yet exposure to high levels of air pollution, including volatile organic compounds (VOCS), is associated with increased GDM risk. We examined the joint effects of ethnic enclaves and VOCs to better understand GDM risk among API women, the group with the highest prevalence of GDM.

Methods: We examined 9069 API births in the Consortium on Safe Labor (19 hospitals, 2002-2008). API ethnic enclaves were defined as areas $\geq 66$ th percentile for percent API residents, dissimilarity (geographic dispersal of API and White residents), and isolation (degree that API individuals interact with another API individual). High levels of 14 volatile organic compounds (VOC) were defined as $\geq 75$ th percentile. Four joint categories were created for each VOC: Low VOC/Enclave (reference group), Low VOC/No Enclave, High VOC/Enclave, High VOC/No Enclave. GDM was reported in medical records. Hierarchical logistic regression estimated odds ratios (OR) and 95\% confidence intervals $(95 \% \mathrm{Cl})$ between joint exposures and GDM, adjusted for maternal factors and area-level poverty. Risk was estimated for 3-months preconception and first trimester exposures.
\end{abstract}

Results: Enclave residence was associated with lower GDM risk regardless of VOC exposure. Preconception benzene exposure was associated with increased risk when women resided outside enclaves [High VOC/No Enclave (OR:3.45, 95\%Cl:1.77,6.72)], and the effect was somewhat mitigated within enclaves, [High VOC/Enclave (OR:2.07, 95\%:1.09, 3.94)]. Risks were similar for 12 of 14 VOCs during preconception and 10 of 14 during the first trimester.

\footnotetext{
*Correspondence: andrew.d.williams@und.edu

'Public Health program, Department of Population Health, School of Medicine \& Health Sciences, University of North Dakota, Room E162, 1301 North Columbia Road Stop 9037, Grand Forks, ND 58202-9037, USA

Full list of author information is available at the end of the article
}

(c) The Author(s). 2021 Open Access This article is licensed under a Creative Commons Attribution 4.0 International License, which permits use, sharing, adaptation, distribution and reproduction in any medium or format, as long as you give appropriate credit to the original author(s) and the source, provide a link to the Creative Commons licence, and indicate if changes were made. The images or other third party material in this article are included in the article's Creative Commons licence, unless indicated otherwise in a credit line to the material. If material is not included in the article's Creative Commons licence and your intended use is not permitted by statutory regulation or exceeds the permitted use, you will need to obtain permission directly from the copyright holder. To view a copy of this licence, visit http://creativecommons.org/licenses/by/4.0/ The Creative Commons Public Domain Dedication waiver (http://creativecommons.org/publicdomain/zero/1.0/) applies to the data made available in this article, unless otherwise stated in a credit line to the data. 
(Continued from previous page)

Conclusions: API residence in non-enclave areas is associated with higher GDM risk, regardless of VOC level. Ethnic enclave residence may mitigate effects of VOC exposure, perhaps due to lower stress levels. The potential benefit of ethnic enclaves warrants further study.

Keywords: Air pollution, Asian/Pacific Islanders, Gestational Diabetes Mellitus, Pregnancy, Volatile Organic Compounds, Ethnic enclave, Stress, Joint exposure

In the United States (U.S.), the Asian/Pacific Islander (API) population increased $72 \%$ between 2000 and 2015, more than any other racial/ethnic group [1]. Approximately $95 \%$ of the U.S. API population is concentrated in metropolitan areas [2], contributing to distinct social and environmental attributes of these areas [3-8]. Despite the concentration of API communities in metropolitan areas, these populations are underrepresented in the environmental health literature, in part due to the 'model minority' myth, which due to high average socioeconomic status, suggests API populations have better health outcomes compared to other racial/ethnic groups $[6,9,10]$. The purpose of this study is to build on previous investigations of contextual health determinants [11, 12] among pregnant API women to provide additional data to better understand the health implications of joint social and environmental exposures among U.S. API communities.

Ethnic enclaves are socially and geographically distinct areas with relatively high concentrations of residents of a similar racial/ethnic ancestry within a metropolitan area [3-5]. Evidence suggests that residence in an ethnic enclave may contribute to better health outcomes among members of the prominent group in that area. Compared to API residents of non-enclave areas, API residents of ethnic enclaves live longer [13] and have lower cancer risk [14]. Evidence among pregnant API women is limited, yet initial findings suggest API women residing in ethnic enclaves seek prenatal care earlier [15] and smoke and use alcohol at lower rates $[11,15,16]$. However, the potentially healthy effect of residence in an ethnic enclave may not be uniform, and may differ by ancestry of the API population. For example, among API populations in the United Kingdom-based Millennium Cohort, ethnic enclave residence increased risk of low birth weight birth among Bangladeshi and Indian mothers, yet was associated with reduced risk of low birth weight among Pakistani mothers [17]. The potential effect of ethnic enclaves among API populations is unclear regarding preterm birth and gestational diabetes mellitus $[11,17,18]$. The potentially healthy effect observed among residents of ethnic enclaves, compared to residents in non-enclave areas is hypothesized to be due to low exposure to discrimination $[19,20]$ and stress [19], which are among the key determinants of health
[21-23]. The reduced exposure to discrimination and stress among ethnic enclave residents is likely due to residents' high levels of political representation and civic participation, as well as greater access to culturallyrelevant goods and services that maintains the resident population's connection to their cultural identity [3-5, 15, 24].

Compared to white communities, communities of color are overburdened with air pollution exposure in the U.S. [6-8, 25] On average, API communities are exposed to similarly high levels of air pollution in comparison to Black and Hispanic communities [6-8, 25]. Additionally, pregnant API women are nearly three times as likely to live in areas with high levels of air pollution compared to pregnant white women [25]. Exposure to high levels of various types of air pollution is associated with systemic inflammation and oxidative stress, which may contribute to poor health outcomes [26-31]. Evidence from animal studies suggest VOCs also induce systemic inflammation and oxidative stress. For instance, among rats, increasing exposure to benzene, a volatile organic compound (VOC), has a linear association with oxidative stress, pancreatic $\beta$-cell dysfunction, and greater insulin resistance [32]. High levels of oxidative stress have been linked with pancreatic $\beta$ cell dysfunction and insulin resistance among humans [30, 31]. Furthermore, API populations have a higher prevalence of genetic variations associated with pancreatic $\beta$-cell dysfunction and insulin resistance than other racial/ethnic groups [33, 34]. While the air pollutionoxidative stress pathway is not specific to API populations, the observed genetic variations may make API populations more susceptible to high levels of air pollution exposure. Thus, the potential interaction between air pollution exposure and social context merits further attention given the potential genetic susceptibility for adverse metabolic outcomes among API populations.

As high exposure to psychosocial stress is associated with immune system dysfunction [35], low exposure to stress among residents of ethnic enclaves suggests more normative immune function. As part of the normative immune response, cells exposed to an insulting agent release pro-inflammatory cytokines and become inflamed in order to isolate damage and protect healthy cells and tissue; as the insult is eliminated, anti-inflammatory 
cytokines are released and inflammation is contained, thus mitigating development of disease [36]. In contrast, air pollution exposure signals an inflammatory response [27, 32, 37-40], and among those with a compromised immune system, an excessive inflammatory response to air pollution may increase risk for metabolic disease [41, 42]. Considering joint social and environmental exposures among API communities in the U.S. will provide new insights into health outcomes among these understudied populations [43]. To the best of our knowledge, joint exposure to residence in ethnic enclaves and air pollution has not yet been examined in pregnant women. Given evidence suggesting residence in ethnic enclaves may be less stressful residential contexts than other areas $[19,20]$, residents of ethnic enclaves more normative immune function may better mitigate the negative health consequences associated with exposure to air pollution compared to those residing elsewhere.

Gestational diabetes mellitus (GDM) presents a unique opportunity to examine joint exposures to ethnic enclaves and air pollution among U.S. API women. In the U.S., API women have the highest prevalence of GDM compared to other racial/ethnic groups [12, 44-52]. GDM is associated with an increased risk of maternal, fetal and neonatal complications, including an increased risk of developing type 2 diabetes mellitus among mothers, and increased risk of obesity and diabetes among offspring [53]. Within the Consortium on Safe Labor (CSL), we observed API women had higher prevalence of GDM (9.9\%) compared to white (4.5\%), Black (4.3\%), and Hispanic (6.4\%) women [12]. Furthermore, in separate studies among the CSL, API women residing in ethnic enclaves had lower risk of GDM compared to API women residing in non-enclave areas [11] and that exposure to high levels of VOCs early in pregnancy was associated with a greater increase in risk of GDM among API women than among women of other racial/ethnic groups [12]. Thus, we hypothesized that pregnant API women residing in an ethnic enclaves were less susceptible to negative consequences of air pollution than pregnant API women residing elsewhere.

\section{Methods}

\section{Data and participants}

The Consortium on Safe Labor (CSL) was a national, electronic medical record-based retrospective cohort study from 2002 to 2008 which included 19 hospitals (8 university teaching hospitals, 9 community teaching hospitals, 2 community hospitals) in 15 Hospital Referral Regions (HRR), catchment areas for tertiary care hospitals [54]. Hospitals were selected based on availability of electronic medical records, and for representation of the 9 American College of Obstetricians and Gynecologists districts [55]. Data were extracted for deliveries $\geq 23$ weeks gestation and include maternal sociodemographic characteristics; medical, reproductive and prenatal history; labor and delivery, and newborn data. A total of 228,438 deliveries were included in the CSL. We excluded multifetal pregnancies $(n=5053 ; 2.21 \%)$, mothers with pre-existing diabetes $(n=3309 ; 1.44 \%)$, and those with missing air pollution exposure information $(n=10$; $.004 \%)$. Including only API mothers resulted in an analytic sample of 9069 births to 8350 mothers. Institutional Review Boards at all sites approved the CSL, and data are anonymous.

\section{Outcome variable}

GDM was drawn from medical record data or in discharge summaries using ICD-9 code 648.8. During the CSL study period (2002-2008), the American Diabetes Associations recommended screening for GDM between 24 and 28 weeks gestation using the Carpenter and Coustan criteria [56].

\section{Ethnic enclave exposure}

In the CSL, area of residence was estimated using the HRR in which the birth occurred. HRR is the only geographic unit of analysis available in the CSL [57]. HRRs are regional geographies (average miles $\left.{ }^{2}: 13,065\right)$ comparable to Metropolitan Statistical Areas [58], with large enough populations (average population size in thousands: 2026) for observable residential sorting [54, 58].

We aggregated sociodemographic data at the zip code tabulation area (ZCTA) level to provide estimates at the HRR level. As HRR are partially defined by ZCTA, we aggregated ZCTA data to the corresponding HRR using year-specific ZCTA to HRR crosswalk from the Dartmouth Atlas of Health Care [54, 58]. ZCTA data was accessed from the National Historical Geographic Information System for the 2000 decennial census, and the 2007-2011 5-year average of the American Community Survey (ACS) [59]. We linked CSL data with yearspecific sociodemographic data: births between 2002 and 2004 were linked with 2000 Census data, and births between 2005 and 2008 were linked with 2007-2011 ACS data $[11,58]$.

We identified ethnic enclaves at the HRR level [11]. HRRs are centered on urban areas, where the majority of U.S. API populations reside [2], yet the regional coverage of HRRs allows for inclusion of potential ethnic enclaves outside of urban centers [60].

Described in Table 1, the distinct social and geographic attributes of an ethnic enclave are represented by API population density and racial/ethnic segregation, defined using three variables $[5,11]$. First, API population density, is measured by the percent of API individuals residing in an HRR. Second, API-White dissimilarity index, is the differential distribution of API 
Table 1 Area-level measures used to identify ethnic enclaves (also described in Williams et al., 2020) [11]

\begin{tabular}{|c|c|c|}
\hline Measure & Formula & Description \\
\hline $\begin{array}{l}\text { API population density } \\
\text { (social attribute) }\end{array}$ & $\left(A_{T} / P_{T}\right) * 100$ & $\begin{array}{l}\text { Percentage of API residents within an HRR. } \\
\text { Range } 0-100 ; 100 \text { suggests HRR consists of only API residents }\end{array}$ \\
\hline $\begin{array}{l}\text { Dissimilarity Index } \\
\text { (geographic attribute) }\end{array}$ & $\frac{1}{2} \sum_{i=1}^{n}\left|\frac{W_{i}}{W_{T}}-\frac{a_{i}}{A_{T}}\right|$ & $\begin{array}{l}\text { Differential distribution of API and White populations within an HRR. } \\
\text { Range } 0-1 \text {; score of } 1 \text { suggests absolute geographic separation of API and White populations within HRR. }\end{array}$ \\
\hline $\begin{array}{l}\text { Isolation Index } \\
\text { (geographic attribute) }\end{array}$ & $\sum_{i=1}^{n}\left(\frac{a_{i}}{A_{T}}\right) *\left(\frac{a_{i}}{P_{T}}\right)$ & $\begin{array}{l}\text { Probability that API residents of an HRR will interaction with another API individual. } \\
\text { Range } 0-1 \text {; score of } 1 \text { suggests an API resident in an HRR will only interact with other API residents. }\end{array}$ \\
\hline Components & \multicolumn{2}{|l|}{ Description } \\
\hline$a_{i}$ & \multicolumn{2}{|c|}{ Number of API in the Zip code } \\
\hline$A_{T}$ & \multicolumn{2}{|c|}{ Number of API in the HRR } \\
\hline$n$ & \multicolumn{2}{|c|}{ Number of Zip codes } \\
\hline$P_{T}$ & \multicolumn{2}{|c|}{ Total population of the HRR } \\
\hline$w_{i}$ & \multicolumn{2}{|c|}{ Number of white in the Zip code } \\
\hline$W_{T}$ & \multicolumn{2}{|c|}{ Number of white in the HRR } \\
\hline
\end{tabular}

and White populations within a geographic area [61, 62]. Lastly, the API isolation index, is the probability that an API individual will interact with another API individual [61, 62]. API population density, API-white dissimilarity index, and API isolation index were calculated separately for Census data and ACS data.

We used population-based percentiles $[4,5,11,18]$ to identify tertiles (low, medium, high) for API population density, API-white dissimilarity, and API isolation. An HRR was considered an ethnic enclave if it was in the upper third of the distribution for all three variables: API population density, API-white dissimilarity, and API isolation [11].

\section{Ambient volatile organic compound exposure}

The Air Quality and Reproductive Health study estimated VOC exposure in the CSL using a modified version of the Community Multiscale Air Quality Model (version 4.7.1), a 3-dimensional, multipollutant air quality model used to predict ambient pollutant levels using 2005 (version 4) National Emission Inventory (NEI) emissions data and Weather Research Forecasting Model meteorological data. The 2005 NEI v4 was used to generate anthropogenic emissions for 2005-2010. Emissions of year 2002 to 2004 and 2006-2010 were adjusted based on the average annual emissions trends. Modified CMAQ models were evaluated at $4 \mathrm{~km}$ and $36 \mathrm{~km}$, and we used $36 \mathrm{~km}$ as the HRR resolution was minimally impacted [57]. Exposure was based on predicted hourly ambient pollutant concentrations within HRRs, fused with local air monitoring data to improve accuracy, and weighted to reflect population concentration and nonresidential areas (i.e. industrial, large parks, water, mountains), as previously described [57].

As GDM screening is recommended between 24 and 28 weeks gestation [56], we averaged the predicted hourly ambient pollutant concentration across preconception (3 months preconception) and first trimester (through 13 weeks gestation) exposure windows. Ambient concentrations (parts per billion; $\mathrm{ppb}$ ) were estimated for 14 VOCs: benzene, 1,3-butadiene, ethylbenzene, cyclohexane, methyl-tertiary-butyl ether, $\mathrm{N}$-hexane, ethyl-methyl ketone, m-xylene, o-xylene, $\mathrm{p}$ xylene, propene, sesquiterpene, styrene, and toluene for each exposure window. Exposure to $\geq 75$ th percentile in $\mathrm{ppb}$ was considered high exposure, and all values $<75$ th percentile in $\mathrm{ppb}$ were considered low exposure.

\section{Joint exposure categories}

Using the categorical ethnic enclave (yes/no) variable, and the categorical VOC (high/low) variable, we created joint exposure categories: Low VOC/Enclave (reference), Low VOC/No Enclave, High VOC/Enclave, High VOC/ No Enclave. The joint exposure variables were created for each of the $14 \mathrm{VOC}$ in both the preconception and first trimester exposure windows.

\section{Covariates}

Individual-level covariates included maternal age, marital status (married, single, other), health insurance (public, private, other), pre-pregnancy body mass index (BMI, < $18.5,18.5-<224.9,25-<29.9, \geq 30$ ), season of conception (winter, spring, summer, fall) and parity (nulliparous or multiparous). As income is not available in the CSL, health insurance [63] and marital status [64] were used as proxies for socioeconomic status. BMI was imputed using multiple imputations (10 iterations) due to a high degree of missingness (42\%).

Area-level poverty (continuous proportion of residents in the HRR living below federal poverty thresholds), hospital type (university teaching hospital, community teaching hospital, and community non-teaching hospital) 
were included as HRR-level covariates. Covariates included in analysis were informed by previous studies $[11,12]$.

\section{Statistical analysis}

Prevalence of GDM was reported for ethnic enclave residence and maternal characteristics, and by joint enclaveVOC exposure. Spearman rank correlations between each of the VOCs were calculated (Supplemental Tables 1 and 2).

Mothers in CSL were nested in HRRs for analysis. Hierarchical logistic regression models were used to estimate the odds ratio (OR) and 95\% confidence intervals for the association between joint VOC/Enclave exposure and GDM, with robust standard errors to account for repeat births to the same mother ( $n=731,7.9 \%$ of births). Low VOC/Enclave exposure category served as reference group as we anticipated this was the lowest risk category. Separate models were run for each of the 14 VOCs for the preconception and first trimester exposure windows, using PROC GLIMMIX and PROC MIAN ALYZE (SAS 9.4) [65]. Benjamini-Hochberg false discovery rate adjustment procedure was used to account for multiple testing [66] (false discovery rate $=10 \%$ ). Analyses were performed using PROC MULTTEST (SAS 9.4) [65].

\section{Sensitivity analyses}

To further disentangle the potential effects of individual component measures (API population density, dissimilarity index or isolation index), we fit separate models to examine the association of ethnic enclaves, and each component part alone, with GDM. The ethnic enclave variable was dichotomous (yes/no), with 'no' serving as the reference category. The component variables were the tertile (low/medium/high) variables used to identify ethnic enclaves, with the 'low' category serving as the reference. Covariates included maternal age, marital status, health insurance, BMI, season of conception, parity, area-level poverty, hospital type, preconception benzene, and first trimester benzene.

Our primary models were single pollutant models but, we recognize that there is correlation between VOCs, and humans are typically exposed to a mixture of VOCs. We conducted a sensitivity analysis to determine if utilizing a measure of VOC mixtures modified results observed in the main analysis. We used Principal Component Analysis (PCA) to identify variables to include in a "multiple high VOCs" exposure category. PCA identified 7 VOCs that were jointly high: benzene, ethylbenzene, toluene, m-xylene, o-xylene, $\mathrm{p}$-xylene, nhexane. These 7 VOCs were jointly high for both preconception and first trimester exposure. If an individual was in the "high" group for all 7 of the VOCs, they were in the new "High Multiple VOC" group. We used this "high multiple VOC" group to identify new VOCEnclave joint categories. Models with the same covariates as the primary models were run to estimate the association between High Multiple VOC/Enclave categories and GDM, with Not High in Multiple VOCs/ Enclave areas serving as reference.

\section{Results}

Of the 9069 pregnancies among API women in the CSL, there were $899(9.9 \%)$ cases of GDM. Table 2 includes distribution of GDM by ethnic enclave residence, maternal characteristics, and area-level covariates. There were 1891 (20.8\%) API women within ethnic enclaves, and 7178 (79.2\%) API women in non-enclave areas. The prevalence of GDM was lower among women in ethnic enclaves (7.5\%) compared to women in non-enclave areas (10.5\%). GDM was more prevalent as BMI and age increased, as well as among multiparous women. GDM was more prevalent among women with private (10.6\%) versus public $(9.7 \%)$, self pay $(9.3 \%)$ or other $(6.5 \%)$ insurance coverage. GDM prevalence differed by season of conception, with warmer months having lower prevalence of GDM compared to colder months. Of note, GDM prevalence did not greatly differ by area-level poverty.

Distribution of GDM by joint VOC/Enclave exposure categories is included in Table 3. For preconception VOC exposure, prevalence of GDM was lowest in Low $\mathrm{VOC} /$ Enclave areas for 7 of 14 VOCs, as anticipated, but was lowest in 6 of 14 High VOC/Enclave areas. For preconception exposure to sesquiterpene, Low VOC/Enclave areas and High VOC/Enclave areas, had the same GDM prevalence (7.5\%). Prevalence of GDM was similar across categories of first trimester VOC exposure. For both preconception and first trimester exposures, nonenclave areas had higher GDM prevalence than enclave areas, regardless of VOC exposure levels.

Hierarchical regression results for the association between VOC/Enclave joint exposure and GDM are reported in Table 4. Compared to Low VOC/Enclave areas, non-enclave areas were generally associated with higher risk of GDM, regardless of VOC exposure levels. For example, preconception benzene exposure was associated with elevated risk for High VOC/No Enclave (OR: 3.45, 95\%CI:1.77, 6.72) and for Low VOC/No Enclave (OR:2.85, 95\%CI:1.57, 5.17), while the risk for High VOC/Enclave (OR:2.07, 95\%:1.09, 3.94) was elevated but somewhat mitigated. There was a similar pattern for 12 of 14 VOC during preconception and 10 of 14 during the first trimester. For example, for propene exposure, risks were similar for both preconception High VOC/No Enclave (OR:1.99, 95\%CI: 1.46, 2.72) and first trimester High VOC/No Enclave (OR:1.96, 95\%CI: 1.44, 2.67). 
Table 2 Frequency (and percent) of GDM status by ethnic enclave residence and maternal characteristics among Asian/Pacific Islander women in the Consortium on Safe Labor among Asian/Pacific Islander women $(n=9069)$

\begin{tabular}{|c|c|c|c|}
\hline \multirow{3}{*}{$\begin{array}{l}\text { Ethnic enclave } \\
\end{array}$} & \multicolumn{2}{|c|}{ Gestational Diabetes Mellitus } & \multirow[t]{2}{*}{$p$-values $^{\mathrm{a}}$} \\
\hline & \multirow[t]{2}{*}{$\begin{array}{l}\text { Yes } \\
(n=899)\end{array}$} & \multirow[t]{2}{*}{$\begin{array}{l}\text { No } \\
(n=8170)\end{array}$} & \\
\hline & & & \\
\hline Yes (1891) & $142(7.5)$ & $1749(92.5)$ & $p<.01$ \\
\hline No (7178) & $757(10.5)$ & $6421(89.5)$ & \\
\hline \multicolumn{4}{|l|}{ Maternal Age } \\
\hline$<20$ years $(168)$ & $4(2.34)$ & $164(97.4)$ & $p<.01$ \\
\hline 20-24 years (1289) & $74(5.7)$ & $1215(94.3)$ & \\
\hline 25-29years (2797) & $226(8.1)$ & $2571(91.9)$ & \\
\hline 30-34 years (2958) & $318(10.8)$ & $2640(89.2)$ & \\
\hline $35+$ years $(1851)$ & $277(15.0)$ & $1574(85.0)$ & \\
\hline Unknown/Missing [6] & $0(0.0)$ & $6(100.0)$ & \\
\hline \multicolumn{4}{|l|}{ Body Mass Index } \\
\hline$\geq 30(425)$ & $75(17.7)$ & $350(82.3)$ & $p<.01$ \\
\hline $25-29.9(744)$ & $111(14.9)$ & $633(85.1)$ & \\
\hline $18.5-24.9(3466)$ & $282(8.1)$ & $3184(91.9)$ & \\
\hline $11.2-18.49(621)$ & $31(5.0)$ & $590(95.0)$ & \\
\hline Unknown (3813) & $400(10.5)$ & 3413 (89.5) & \\
\hline \multicolumn{4}{|l|}{ Insurance Type } \\
\hline Private (6374) & $677(10.6)$ & $5697(89.4)$ & $p<.01$ \\
\hline Public (1280) & $124(9.7)$ & $1156(90.3)$ & \\
\hline Self Pay (193) & $18(9.3)$ & $175(90.7)$ & \\
\hline Other (1222) & $80(6.5)$ & $1142(93.5)$ & \\
\hline \multicolumn{4}{|l|}{ Marital Status } \\
\hline Married (7642) & $800(10.5)$ & $6842(89.5)$ & $p<.01$ \\
\hline Single (1241) & $78(6.3)$ & $1163(93.7)$ & \\
\hline Divorced (186) & $21(11.3)$ & $165(88.7)$ & \\
\hline \multicolumn{4}{|l|}{ Parity } \\
\hline $0(4433)$ & $395(8.9)$ & $4038(91.1)$ & $p<.01$ \\
\hline$\geq 1$ (4636) & $504(10.9)$ & $4132(89.1)$ & \\
\hline \multicolumn{4}{|l|}{ Hospital Type } \\
\hline University Affiliated (3716) & $329(8.9)$ & 3387 (91.1) & $p<.01$ \\
\hline Community: Teaching (4948) & $541(10.9)$ & 4407 (89.1) & \\
\hline Community: Non-teaching (405) & $29(7.2)$ & $376(92.8)$ & \\
\hline \multicolumn{4}{|l|}{ Season of Conception } \\
\hline March-May (2140) & $203(9.5)$ & $1937(90.5)$ & $p=.05$ \\
\hline June-August (2363) & $208(8.8)$ & $2155(91.2)$ & \\
\hline September-November (2437) & $250(10.3)$ & $2187(89.7)$ & \\
\hline December-February (2129) & $238(11.2)$ & $1891(88.8)$ & \\
\hline \multicolumn{4}{|l|}{ Area-Level Poverty } \\
\hline$\geq 15.9 \%$ (3323) & $348(10.5)$ & $2975(89.5)$ & $p=.17$ \\
\hline$<15.9 \%(5746)$ & $551(9.6)$ & $5195(90.4)$ & \\
\hline
\end{tabular}

${ }^{a} P$-values obtain using generalized estimating equations to account for women with $>1$ pregnancy 
Table 3 Frequency (and percent) of gestational diabetes mellitus status by joint preconception VOC-Enclave category among Asian/ Pacific Islander women in the Consortium on Safe Labor (2002-2008)

\begin{tabular}{|c|c|c|c|c|c|c|c|c|c|c|}
\hline \multirow{2}{*}{$\begin{array}{l}\text { VOC } \\
\text { (High }=\geq 75 \text { th } \\
\text { percentile) }\end{array}$} & & \multirow[b]{2}{*}{ Enclave } & \multicolumn{4}{|c|}{ Preconception } & \multicolumn{4}{|c|}{ First Trimester } \\
\hline & & & $\begin{array}{l}\mathrm{n} \\
(N=9069)\end{array}$ & $\begin{array}{l}\text { GDM } \\
(N=899)\end{array}$ & No GDM $(n=8170)$ & $p$ value $^{a}$ & $\begin{array}{l}\mathrm{n} \\
(N=9069)\end{array}$ & $\begin{array}{l}\text { GDM } \\
(N=899)\end{array}$ & No GDM $(n=8170)$ & $p$ value $^{\mathrm{a}}$ \\
\hline \multirow[t]{4}{*}{ Benzene } & Low & Yes & 242 & $13(5.3)$ & $229(94.6)$ & $p<.01$ & 245 & $15(6.1)$ & $230(93.9)$ & $p<.01$ \\
\hline & & No & 4115 & $415(10.0)$ & $3700(90.0)$ & & 4179 & $420(10.0)$ & $3759(90.0)$ & \\
\hline & High & Yes & 1649 & $129(7.8)$ & $1520(92.2)$ & & 1646 & $127(7.7)$ & $1519(92.3)$ & \\
\hline & & No & 3063 & $342(11.1)$ & $2721(88.9)$ & & 2999 & $337(11.2)$ & $2662(88.8)$ & \\
\hline \multirow[t]{4}{*}{ Ethylbenzene } & Low & Yes & 245 & $15(6.1)$ & $230(93.9)$ & $p<.01$ & 245 & $15(6.1)$ & $230(93.9)$ & $p<.01$ \\
\hline & & No & 3916 & $406(10.3)$ & $3510(89.7)$ & & 3943 & $412(10.4)$ & 3531 (89.6) & \\
\hline & High & Yes & 1646 & $127(7.7)$ & $1519(92.3)$ & & 1646 & $127(7.7)$ & $1519(92.3)$ & \\
\hline & & No & 3262 & $351(10.7)$ & $2911(89.3)$ & & 3235 & $345(10.6)$ & $2890(89.4)$ & \\
\hline \multirow[t]{4}{*}{ MTB Ether } & Low & Yes & 738 & $63(8.5)$ & $675(91.5)$ & $p<.01$ & 596 & $50(8.4)$ & $546(91.6)$ & $p<.01$ \\
\hline & & No & 4578 & $437(9.5)$ & $4141(90.5)$ & & 4436 & $419(9.4)$ & 4017 (90.6) & \\
\hline & High & Yes & 1153 & $79(6.9)$ & $1074(93.1)$ & & 1295 & $92(7.1)$ & 1203 (92.9) & \\
\hline & & No & 2600 & $320(12.3)$ & $2280(87.7)$ & & 2742 & 338 (12.3) & $2404(87.7)$ & \\
\hline \multirow[t]{4}{*}{ N-hexane } & Low & Yes & 535 & $44(8.22)$ & 491 (91.8) & $p<.01$ & 410 & $32(7.8)$ & $378(92.2)$ & $p<.01$ \\
\hline & & No & 3834 & 373 (9.7) & 3461 (90.3) & & 3984 & $388(9.7)$ & 3596 (90.3) & \\
\hline & High & Yes & 1356 & $98(7.2)$ & $1258(92.8)$ & & 1481 & $110(7.4)$ & 1371 (92.6) & \\
\hline & & No & 3344 & 384 (11.5) & $2960(88.5)$ & & 3194 & 369 (11.5) & 2825 & \\
\hline \multirow[t]{4}{*}{ EMK } & Low & Yes & 739 & $58(7.8)$ & $681(92.2)$ & $p<.01$ & 627 & $54(8.6)$ & $573(91.4)$ & $p<.01$ \\
\hline & & No & 4827 & $490(10.1)$ & $4337(89.9)$ & & 4615 & $460(9.9)$ & 4155 (90.1) & \\
\hline & High & Yes & 1152 & $84(7.3)$ & 1068 (92.7) & & 1264 & $88(6.9)$ & 1176 (93.1) & \\
\hline & & No & 2351 & $267(11.3)$ & 2084 (88.7) & & 2563 & 297 (11.6) & 2266 (88.4) & \\
\hline \multirow[t]{4}{*}{ m-xylene } & Low & Yes & 245 & $15(6.1)$ & $230(93.9)$ & $p<.01$ & 245 & $15(6.1)$ & $230(93.9)$ & $p<.01$ \\
\hline & & No & 3909 & $408(10.4)$ & 3501 (89.6) & & 3926 & $410(10.4)$ & 3516 (89.6) & \\
\hline & High & Yes & 1646 & $127(7.7)$ & 1519 (92.3) & & 1646 & $127(7.7)$ & 1519 (92.3) & \\
\hline & & No & 3269 & 349 (10.7) & $2920(89.3)$ & & 3252 & 347 (10.7) & 2905 (89.3) & \\
\hline \multirow[t]{4}{*}{ o-xylene } & Low & Yes & 304 & $18(5.9)$ & $286(94.1)$ & $p<.01$ & 246 & $15(6.1)$ & $231(93.9)$ & $p<.01$ \\
\hline & & No & 3897 & $405(10.4)$ & 3492 (89.6) & & 3936 & $410(10.4)$ & 3526 (89.6) & \\
\hline & High & Yes & 1587 & $124(7.8)$ & 1463 (92.2) & & 1645 & $127(7.7)$ & 1518 (92.3) & \\
\hline & & No & 3281 & $352(10.7)$ & $2929(89.3)$ & & 3242 & 347 (10.7) & 2895 (89.3) & \\
\hline \multirow[t]{4}{*}{ p-xylene } & Low & Yes & 438 & $31(7.1)$ & 407 (92.9) & $p<.01$ & 338 & $24(7.1)$ & 314 (92.9) & $p<.01$ \\
\hline & & No & 3868 & 399 (10.3) & $3469(89.7)$ & & 3900 & $406(10.4)$ & 3494 (89.6) & \\
\hline & High & Yes & 1453 & $111(7.6)$ & $1342(92.4)$ & & 1553 & $118(7.6)$ & 1435 (92.4) & \\
\hline & & No & 3310 & $358(10.8)$ & $2952(89.2)$ & & 3278 & $351(10.7)$ & 2927 (89.3) & \\
\hline \multirow[t]{4}{*}{ Propene } & Low & Yes & 827 & $67(8.1)$ & 760 (91.9) & $p<.01$ & 945 & $74(7.8)$ & $871(92.2)$ & $p<.01$ \\
\hline & & No & 4728 & $449(9.5)$ & $4279(90.5)$ & & 4471 & $420(9.4)$ & 4051 (90.6) & \\
\hline & High & Yes & 1064 & $75(7.1)$ & 989 (92.9) & & 946 & $68(7.1)$ & $878(92.9)$ & \\
\hline & & No & 2450 & 308 (12.6) & $2142(87.4)$ & & 2707 & 337 (12.5) & $2370(87.5)$ & \\
\hline \multirow[t]{4}{*}{ Sesquiterpene } & Low & Yes & 818 & $62(7.5)$ & $756(92.5)$ & $p<.01$ & 741 & $62(8.4)$ & 679 (91.6) & $p<.01$ \\
\hline & & No & 3753 & $355(9.5)$ & $3398(90.5)$ & & 3841 & $360(9.4)$ & 3481 (90.6) & \\
\hline & High & Yes & 1073 & $80(7.5)$ & $993(92.5)$ & & 1150 & $80(6.9)$ & 1070 (93.1) & \\
\hline & & No & 3425 & $402(11.7)$ & $3023(88.2)$ & & 3337 & 397 (11.9) & $2940(88.1)$ & \\
\hline Toluene & Low & Yes & 334 & $19(5.7)$ & $315(94.3)$ & $p<.01$ & 245 & $15(6.1)$ & $230(93.9)$ & $p<.01$ \\
\hline
\end{tabular}


Table 3 Frequency (and percent) of gestational diabetes mellitus status by joint preconception VOC-Enclave category among Asian/ Pacific Islander women in the Consortium on Safe Labor (2002-2008) (Continued)

\begin{tabular}{|c|c|c|c|c|c|c|c|c|c|c|}
\hline \multirow[b]{2}{*}{$\begin{array}{l}\text { VOC } \\
\text { (High }=\geq 75 \text { th } \\
\text { percentile) }\end{array}$} & & \multirow[b]{2}{*}{ Enclave } & \multicolumn{4}{|c|}{ Preconception } & \multicolumn{4}{|c|}{ First Trimester } \\
\hline & & & $\begin{array}{l}\mathrm{n} \\
(N=9069)\end{array}$ & $\begin{array}{l}\text { GDM } \\
(N=899)\end{array}$ & No GDM $(n=8170)$ & $p$ value $^{a}$ & $\begin{array}{l}\mathrm{n} \\
(N=9069)\end{array}$ & $\begin{array}{l}\text { GDM } \\
(N=899)\end{array}$ & No GDM $(n=8170)$ & $p$ value $^{a}$ \\
\hline & & No & 3891 & $407(10.5)$ & 3484 (89.5) & & 3934 & $411(10.5)$ & 3523 (89.5) & \\
\hline & High & Yes & 1557 & $123(7.9)$ & $1434(92.1)$ & & 1646 & $127(7.7)$ & 1519 (92.3) & \\
\hline & & No & 3287 & 350 (10.6) & 2937 (89.4) & & 3244 & $346(10.7)$ & 2898 (89.3) & \\
\hline \multirow[t]{4}{*}{ Styrene } & Low & Yes & 736 & $64(8.7)$ & $672(91.3)$ & $p<.01$ & 619 & $52(8.4)$ & 567 (91.6) & $p<.01$ \\
\hline & & No & 6268 & $657(10.5)$ & 5611 (89.5) & & 6266 & $661(10.6)$ & 5605 (89.4) & \\
\hline & High & Yes & 1155 & $78(6.7)$ & 1077 (93.3) & & 1272 & $90(7.1)$ & 1182 (92.9) & \\
\hline & & No & 910 & $100(11.0)$ & $810(89.0)$ & & 912 & $96(10.5)$ & 816 (89.5) & \\
\hline \multirow[t]{4}{*}{ 1,3 butadiene } & Low & Yes & 732 & $64(8.7)$ & $668(91.3)$ & $p<.01$ & 595 & $51(8.6)$ & $544(91.4)$ & $p<.01$ \\
\hline & & No & 6197 & $642(10.4)$ & 5555 (89.6) & & 6354 & $673(10.6)$ & 5681 (89.4) & \\
\hline & High & Yes & 1159 & $78(6.7)$ & 1081 (92.3) & & 1296 & $91(7.0)$ & 1205 (93.0) & \\
\hline & & No & 981 & 115 (11.7) & $866(88.3)$ & & 824 & $84(10.1)$ & 740 (89.9) & \\
\hline \multirow[t]{4}{*}{ Cyclohexane } & Low & Yes & 1022 & $66(6.5)$ & 956 (93.5) & $p<.01$ & 1016 & $74(7.3)$ & $942(92.7)$ & $p<.01$ \\
\hline & & No & 3747 & 391 (10.4) & 3356 (89.6) & & 3794 & $400(10.5)$ & 3394 (89.5) & \\
\hline & High & Yes & 869 & $76(8.7)$ & 793 (91.3) & & 875 & $68(7.8)$ & $807(92.3)$ & \\
\hline & & No & 3431 & 366 (10.7) & 3065 (89.3) & & 3384 & 357 (10.6) & 3027 (89.5) & \\
\hline
\end{tabular}

${ }^{a} P$-values obtain using generalized estimating equations to account for women who had more than one pregnancy in the study

Results of the enclave components sensitivity analysis are shown in Table 5. Residence in an ethnic enclave was associated with $49 \%$ lower odds of GDM (OR:0.51, $95 \%$ CI:0.37, 0.69) compared to residence in a nonenclave area. For the ethnic enclave components, high API population density was associated with a $38 \%$ lower odds of GDM (OR:0.62, 95\%CI: $0.46,0.83$ ) compared to low API population density. Additionally, high levels of dissimilarity (OR: 0.81, 95\% CI:0.64, 1.08) and isolation (OR: $0.83,95 \%$ CI:0.64, 1.07) suggest a potential healthy effect compared to respective low levels.

The "high multiple VOC" sensitivity analysis results are consistent and presented in Supplemental Table 3. Compared to Not High in Multiple VOCs/Enclave areas, non-enclave areas were associated with higher risk of GDM, regardless of VOC exposure levels. Results were similar across exposure windows. For example, High in Multiple VOCs/Non-Enclave was associated with approximately $75 \%$ increased risk of GDM in preconception (OR: 1.74 95\%CI: 1.12, 2.69) and first trimester (OR: 1.75 95\%CI: 1.08, 2.86) exposure windows.

\section{Discussion}

In this first investigation of the association between joint exposure to air pollution and residence in an ethnic enclave and GDM risk, we found evidence that residence within an ethnic enclave may mitigate negative consequences of environmental exposures. In line with evidence of an association between preconception and first trimester exposure to air pollution and increased risk of GDM [12, 28, 67-69] as well as evidence of lower risk of GDM among women residing within ethnic enclaves $[11,17,18]$ we found evidence that residence in enclaves is associated with lower GDM risk, regardless of VOC level.

The observations suggest chronic exposure to residence outside of ethnic enclaves and VOCs are associated with increased GDM risk for API mothers, as risks appear consistent across preconception and first trimester exposure windows. Previously among women in the CSL, we have observed consistent increases in GDM risk across preconception and first trimester exposure windows for criteria air pollutants such as nitrogen oxides and sulfur dioxide [28], as well as VOCs [12]. Similar observations of chronic exposure to criteria air pollutants and GDM were observed among women in Denmark, Sweden, and Taiwan [67-69]. Given that air pollution and ethnic enclave exposures are likely chronic, the development of GDM is likely not due to an acute exposure in pregnancy.

As ethnic enclave residence appears to mitigate the negative consequences of VOC exposure, these observations suggest immunologic function may be an important factor. The normative immunologic response to air pollution, including during pregnancy [27], induces proinflammatory responses evidenced by heightened cytokine production and serum c-reactive protein levels [27, 32, 37-40]. Exposure to chronic stress leads to excessive 
Table 4 Joint associations between exposure to ambient volatile organic compounds, ethnic enclaves, and gestational diabetes mellitus among Asian/Pacific Islander women in the Consortium on Safe Labor (2002-2008)

\begin{tabular}{|c|c|c|c|c|c|c|}
\hline \multirow{2}{*}{\multicolumn{2}{|c|}{$\begin{array}{l}\text { VOC } \\
\text { (High }=\geq 75 \text { th percentile) }\end{array}$}} & \multirow{3}{*}{$\begin{array}{l}\text { Enclave } \\
\text { Yes }\end{array}$} & \multicolumn{2}{|c|}{ Preconception } & \multicolumn{2}{|c|}{ First Trimester } \\
\hline & & & \multirow{2}{*}{$\begin{array}{l}\mathbf{n} \\
(N=9069) \\
242\end{array}$} & \multirow{2}{*}{$\begin{array}{l}\begin{array}{l}\text { Odds Ratio } \\
(95 \% \mathrm{Cl})\end{array} \\
\text { Ref. }\end{array}$} & \multirow{2}{*}{$\begin{array}{l}\mathbf{n} \\
(N=9069) \\
245\end{array}$} & \multirow{2}{*}{$\begin{array}{l}\begin{array}{l}\text { Odds Ratio } \\
(95 \% \mathrm{Cl})\end{array} \\
\text { Ref. }\end{array}$} \\
\hline Benzene & Low & & & & & \\
\hline & & No & 4115 & $2.85(1.57,5.17)^{a}$ & 4179 & $2.38(1.36,4.16)^{2}$ \\
\hline & High & Yes & 1649 & $2.07(1.09,3.94)^{a}$ & 1646 & $1.65(0.90,3.03)$ \\
\hline & & No & 3063 & $3.45(1.77,6.72)^{a}$ & 2999 & $2.70(1.45,5.03)^{a}$ \\
\hline \multirow[t]{4}{*}{ Ethylbenzene } & Low & Yes & 245 & Ref. & 245 & Ref. \\
\hline & & No & 3916 & $2.43(1.37,4.32)^{a}$ & 3943 & $2.30(1.29,4.09)^{a}$ \\
\hline & High & Yes & 1646 & $1.70(0.90,3.22)$ & 1646 & $1.56(0.82,2.95)$ \\
\hline & & No & 3262 & $2.76(1.32,5.75)^{a}$ & 3235 & $2.29(1.10,4.77)^{c}$ \\
\hline \multirow[t]{4}{*}{ MTB Ether } & Low & Yes & 738 & Ref. & 596 & Ref. \\
\hline & & No & 4578 & $1.38(1.02,1.87)^{a}$ & 4436 & $1.40(1.01,1.95)$ \\
\hline & High & Yes & 1153 & $0.87(0.58,1.31)$ & 1295 & $0.90(0.60,1.36)$ \\
\hline & & No & 2600 & $1.84(1.34,2.52)^{a}$ & 2742 & $1.88(1.33,2.66)^{2}$ \\
\hline \multirow[t]{4}{*}{ N-hexane } & Low & Yes & 535 & Ref. & 410 & Ref. \\
\hline & & No & 3834 & $1.56(1.11,2.20)^{a}$ & 3984 & $1.72(1.16,2.55)^{a}$ \\
\hline & High & Yes & 1356 & $1.03(0.68,1.57)$ & 1481 & $1.16(0.74,1.83)$ \\
\hline & & No & 3344 & $2.09(1.39,3.15)^{a}$ & 3194 & $2.25(1.43,3.53)^{a}$ \\
\hline \multirow[t]{4}{*}{ EMK } & Low & Yes & 739 & Ref. & 627 & Ref. \\
\hline & & No & 4827 & $1.62(1.19,2.20)^{a}$ & 4615 & $1.43(1.04,1.96)^{2}$ \\
\hline & High & Yes & 1152 & $1.09(0.72,1.63)$ & 1264 & $0.85(0.57,1.28)$ \\
\hline & & No & 2351 & $1.84(1.32,2.58)^{a}$ & 2563 & $1.67(1.18,2.36)^{a}$ \\
\hline \multirow[t]{4}{*}{ m-xylene } & Low & Yes & 245 & Ref. & 245 & Ref. \\
\hline & & No & 3909 & $2.33(1.31,4.15)^{a}$ & 3926 & $2.30(1.29,4.08)^{a}$ \\
\hline & High & Yes & 1646 & $1.59(0.84,3.01)$ & 1646 & $1.55(0.82,2.94)$ \\
\hline & & No & 3269 & $2.40(1.15,5.00)^{a}$ & 3252 & $2.27(1.08,4.76)^{a}$ \\
\hline \multirow[t]{4}{*}{ o-xylene } & Low & Yes & 304 & Ref. & 246 & Ref. \\
\hline & & No & 3897 & $2.37(1.42,3.98)^{a}$ & 3936 & $2.35(1.32,4.17)^{a}$ \\
\hline & High & Yes & 1587 & $1.66(0.94,2.94)$ & 1645 & $1.60(0.85,3.04)$ \\
\hline & & No & 3281 & $2.52(1.30,4.87)^{a}$ & 3242 & $2.42(1.15,5.09)^{a}$ \\
\hline \multirow[t]{4}{*}{ p-xylene } & Low & Yes & 438 & Ref. & 338 & Ref. \\
\hline & & No & 3868 & $1.87(1.25,2.78)^{a}$ & 3900 & $1.93(1.23,3.03)^{a}$ \\
\hline & High & Yes & 1453 & $1.27(0.80,2.03)$ & 1553 & $1.29(0.77,2.16)$ \\
\hline & & No & 3310 & $2.02(1.20,3.40)^{a}$ & 3278 & $1.93(1.06,3.53)^{a}$ \\
\hline \multirow[t]{4}{*}{ Propene } & Low & Yes & 827 & Ref. & 945 & Ref. \\
\hline & & No & 4728 & $1.44(1.07,1.93)^{a}$ & 4471 & $1.45(1.09,1.93)^{a}$ \\
\hline & High & Yes & 1064 & $0.93(0.64,1.36)$ & 946 & $0.94(0.66,1.34)$ \\
\hline & & No & 2450 & $1.99(1.46,2.72)^{a}$ & 2707 & $1.96(1.44,2.67)^{a}$ \\
\hline \multirow[t]{4}{*}{ Sesquiterpene } & Low & Yes & 818 & Ref. & 741 & Ref. \\
\hline & & No & 3753 & $1.55(1.15,2.10)^{a}$ & 3841 & $1.38(1.02,1.87)^{a}$ \\
\hline & High & Yes & 1073 & $1.13(0.77,1.65)$ & 1150 & $0.87(0.59,1.28)$ \\
\hline & & No & 3425 & $2.23(1.59,3.14)^{a}$ & 3337 & $1.91(1.36,2.69)^{a}$ \\
\hline \multirow[t]{2}{*}{ Toluene } & Low & Yes & 334 & Ref. & 245 & Ref. \\
\hline & & No & 3891 & $2.39(1.45,3.95)^{a}$ & 3934 & $2.31(1.30,4.11)^{2}$ \\
\hline
\end{tabular}


Table 4 Joint associations between exposure to ambient volatile organic compounds, ethnic enclaves, and gestational diabetes mellitus among Asian/Pacific Islander women in the Consortium on Safe Labor (2002-2008) (Continued)

\begin{tabular}{|c|c|c|c|c|c|c|}
\hline \multirow{2}{*}{\multicolumn{2}{|c|}{$\begin{array}{l}\text { voC } \\
\text { (High }=\geq 75 \text { th percentile) }\end{array}$}} & \multirow{3}{*}{$\begin{array}{l}\text { Enclave } \\
\text { Yes }\end{array}$} & \multicolumn{2}{|c|}{ Preconception } & \multicolumn{2}{|c|}{ First Trimester } \\
\hline & & & \multirow{2}{*}{$\begin{array}{l}\mathbf{n} \\
(N=9069) \\
1557\end{array}$} & \multirow{2}{*}{$\begin{array}{l}\begin{array}{l}\text { Odds Ratio } \\
(95 \% \mathrm{Cl})\end{array} \\
1.68(0.96,2.91)\end{array}$} & \multirow{2}{*}{$\begin{array}{l}\mathbf{n} \\
(N=9069) \\
1646\end{array}$} & \multirow{2}{*}{$\begin{array}{l}\begin{array}{l}\text { Odds Ratio } \\
\text { (95\% Cl) }\end{array} \\
1.57(0.83,2.97)\end{array}$} \\
\hline & High & & & & & \\
\hline & & No & 3287 & $2.38(1.25,4.52)^{a}$ & 3244 & $2.31(1.09,4.89)^{a}$ \\
\hline \multirow[t]{4}{*}{ Styrene } & Low & Yes & 736 & Ref. & 619 & Ref. \\
\hline & & No & 6268 & $1.41(1.04,1.93)^{a}$ & 6266 & $1.47(1.05,2.06)^{a}$ \\
\hline & High & Yes & 1155 & $0.84(0.56,1.26)$ & 1272 & $0.89(0.59,1.34)$ \\
\hline & & No & 910 & $1.59(1.13,2.24)^{a}$ & 912 & $1.56(1.08,2.25)^{a}$ \\
\hline \multirow[t]{4}{*}{ 1,3 butadiene } & Low & Yes & 732 & Ref. & 595 & Ref. \\
\hline & & No & 6197 & $1.39(1.02,1.88)^{a}$ & 6354 & $1.48(1.06,2.06)^{a}$ \\
\hline & High & Yes & 1159 & $0.83(0.55,1.25)$ & 1296 & $0.86(0.57,1.29)$ \\
\hline & & No & 981 & $1.67(1.19,2.33)^{a}$ & 824 & $1.46(1.01,2.13)^{a}$ \\
\hline \multirow[t]{4}{*}{ Cyclohexane } & Low & Yes & 1022 & Ref. & 1016 & Ref. \\
\hline & & No & 3747 & $1.86(1.37,2.53)^{a}$ & 3794 & $1.70(1.26,2.28)^{a}$ \\
\hline & High & Yes & 869 & $1.31(0.92,1.87)$ & 875 & $1.08(0.76,1.54)$ \\
\hline & & No & 3431 & $1.73(1.15,2.59)^{a}$ & 3384 & $1.46(0.98,2.18)$ \\
\hline
\end{tabular}

Analytic sample restricted to Asian/Pacific Islander women without diagnosed preconception diabetes. Hierarchical logistic regression, women nested within hospital referral region. Models adjusted for maternal age, preconception BMI, parity, insurance status, hospital, marital status, area-level poverty, season of birth

${ }^{a}$ statistically significant after Benjamini-Hochberg procedure (false discovery rate $=10 \%$ )

release of stress hormones resulting in physiologic dysregulation, including impaired immune function, and consequent excessive inflammation [42, 43]. Evidence of immune function in regards to ethnic enclave residence is seen among Hispanic women, as those residing in ethnic enclaves have lower risk of allostatic load (dysfunction across multiple physiologic domains including impaired immune function), compared to those residing in non-enclave areas [20]. Impaired immunologic function may respond to air pollution exposure with excessive inflammation, resulting in excessive release of proinflammatory cytokines and damage to healthy cells, which in turn can lead to insulin resistance, a precursor to metabolic disease [41, 42]. Thus, the similar systemic inflammatory and oxidative stress responses between exposure to chronic stress and exposure to air pollution may explain the synergic effects between residence in non-enclave areas and exposure to high levels of VOCs.
Our findings are also in line with evidence suggesting that the deleterious effect of air pollution on health is stronger among those residing in more stressful contexts. For instance, the effect estimates for exposure to high levels of VOCs with poor cardiometabolic health are higher among adolescents residing in high-poverty areas compared to those residing in low-poverty areas [70]. Additionally, criteria air pollution exposure during the first year of life is associated with increased risk of childhood asthma, but only among children in high poverty areas [71]. It is noteworthy that the observed GDM risks were independent of individual-level proxies of health insurance and marital status, suggesting residence in an ethnic enclave may buffer the negative consequences of exposure to high levels of air pollution.

The results of the enclaves components sensitivity analysis suggest our measure of ethnic enclaves better depicts the unique social and geographic attributes of API

Table 5 Sensitivity analysis: Association between ethnic enclaves and component measures and gestational diabetes mellitus

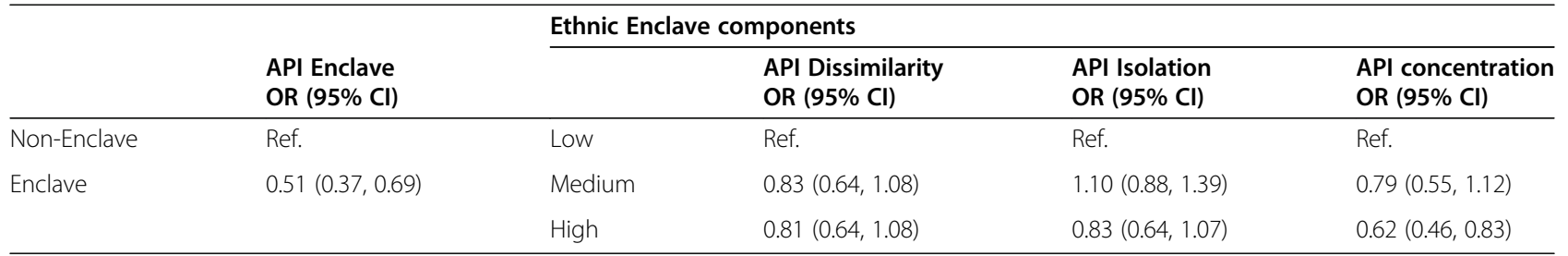

Models adjusted for maternal age, marital status, health insurance, BMI, season of conception, parity, area-level poverty, hospital type, preconception benzene, and first trimester benzene 
ethnic enclaves than any of the individual components do alone (Table 5). While high levels of dissimilarity index, isolation index, and population density suggest a potential healthy effect, the healthy effect is greatest in those areas identified as API ethnic enclaves. The combination of dissimilarity index, isolation index, and population density allowed us to identify areas that were geographically distinct, and with a large enough population of API residents to be socially distinct. This definition of API ethnic enclaves could be refined by inclusion of more culturally-relevant data such as ancestry data, immigration data, and language data.

The results of the "high multiple VOC" analysis do not change the interpretation that ethnic enclaves are protective against the negative effects of air pollution. While PCA solves the potential VOC inter-correlation problem, it does not allow for examination of specific exposures that may be related to particular sources, or for confirmation from animal or occupational studies which might focus on individual compounds. Additionally, given the observed effects of the "high multiple VOC" approach greatly differs from several individual VOCs, this "high multiple VOC" approach may be masking especially harmful VOCs. Since examination of VOCs is novel in regards to GDM, we want to maintain the individual exposures. We believe this specificity can encourage occupational and animal studies to potentially confirm our findings.

Our observations highlight the importance of focusing on API communities in environmental health research. API communities are often aggregated in research and identified as 'model minorities' due to higher socioeconomic status compared to other non-white racial/ethnic groups in the U.S., suggesting API communities have favorable health outcomes compared to other racial/ethnic groups [6,9]. Reliance on the 'model minority' label, in addition to API encompassing approximately $6 \%$ of the U.S. population, contributes to limited representation of API populations in national datasets, the homogenization of API ancestry by aggregation across distinct countries of origin, poor recognition of disparities among API populations, and a lack of environmental justice research targeting API communities [6-9]. By aggregating API ancestry groups, important differences in health status and environmental exposures may be masked, thus representing the same level of risk for poor health outcomes among a diverse group. The lack of relevant data excludes API communities from environmental health policy and health promotion planning when they may be an at-risk group [7, 9]. Given known health disparities, adverse environmental exposures, and the need for data disaggregation among API communities, public health surveillance and research should increase efforts to collect ancestry-specific and culturally- specific data to better address disparities impacting API communities.

In order to improve health outcomes among U.S. API populations, it could be beneficial for API communities to implement culturally-specific efforts to jointly improve social and environmental conditions. Previous attempts to improve environmental conditions have failed when a community's cultural considerations have not been taken into account, resulting in worse environmental conditions and rapid displacement and gentrification [72-74]. API communities in California have been successful in community-led efforts to assemble multisector coalitions to implement environmentally friendly transportation and infrastructure improvements, affordable housing developments, and economic vitalization that reflect cultural values of API communities [72]. However, further research is warranted to better understand the population-health benefits of these community-led efforts.

Our findings are notable for several reasons. First, to the best of our knowledge, this is the initial investigation of joint exposure to air pollution and residence in an ethnic enclave among pregnant women. The observations that residence within an ethnic enclave mitigates air pollution suggest chronic exposure to low or high stress prior to pregnancy has important physiologic implications during pregnancy. Secondly, this study expands our understanding of complex socioenvironmental exposures among an understudied minority population. API communities are at greater risk for high air pollution exposure, and are typically concentrated within urban areas in the U.S. Lastly, this study benefits from a large amount of clinical data for a large sample of API women in the CSL. This allows for a robust examination of community-level risk factors for GDM, a condition that disproportionately affects U.S. API women.

These findings are best considered in the context of the study's limitations. Our measure of ethnic enclaves has not been validated in studies outside of the CSL [11], as to the best of or our knowledge, no validated measure of ethnic enclaves exists. Given HRR is the sole geographic unit of analysis in the CSL, our measurement of ethnic enclaves was informed by previous studies in order to best capture social and geographic distinctions of ethnic enclaves. API women in the CSL are aggregated into a single category, not allowing us to examine API women by ancestry. Due to this, we used the aggregated API census data to measure ethnic enclaves. This limits our observations as API ancestry may be related to GDM risk [18], and air pollution exposure [6, 75], and effect of ethnic enclave residence may differ by API ancestry $[17,18]$. However, previous analyses suggest the API population of metropolitan areas represented in the 
CSL is over 93\% women of Asian ancestry with relatively few Pacific Islander women [12]. The CSL lacks maternal residential history, limiting our understanding of length of exposure to ethnic enclaves. However, most residential relocation during pregnancy occurs with a similar geographic area, and cross-sectional data allows for an approximate understanding of chronic exposures to community-level factors [76].

Immigration history for women within the CSL is not available, thus, examination of differences by immigration status is not possible. From our previous analysis of API ethnic enclaves in the CSL, the API population within metropolitan areas represented in the CSL is over $65 \%$ foreign born [11], suggesting potential acculturation to U.S. norms or a healthy migrant effect may affect our results. More detailed immigration data may allow for additional explorations of acculturation and healthy migrant in the context of ethnic enclaves.

Overall, we applied a conservative strategy for estimating VOC exposure, averaging over broader time and space dimensions to provide more stable estimates. Due to this approach, these observations are likely biased towards the null for several reasons. We averaged VOC exposure over the HRR, which reduces the impact of small point source exposure. We note that there is larger degree of uncertainty in CMAQ models with respect to population-level VOC exposures compared to exposure to ambient criteria air pollutants, such as PM and ozone. To account for this, we examined a dichotomous high/ low VOC exposure variable as we did not assume VOCs were measured well enough to estimate linear relationships and there is no routine VOC monitoring data to fuse to the modified CMAQ data. We recognize a more robust continuous estimate may elucidate these relationships and better describe biologic mechanisms, as well as provide more information for regulatory decisions. We encourage other researchers with more robust VOC data, such as air pollution estimates from CMAQ-CB6 [77], to further analyze this question with better spatial resolution.

VOC exposure was averaged over HRRs in which the birth occurred and was not based on participant residence or specific location of ethnic enclaves. However, our enclave and exposure estimates are based on the areas covered by the HRR under the assumption that most women will live in the catchment area of their delivery hospital. Exposure misclassification may occur if mothers resided outside the HRR for all or part of their pregnancy. However, while $10-30 \%$ of pregnant women change residence during pregnancy, most move to an area of similar level of air pollution [78, 79]. Misclassification may also be a function of local mobility and activity patterns of pregnant women. While the CSL does not have local mobility or daily activity data, current evidence suggests pregnant women and a general population comparison group both spent approximately $15 \mathrm{~h}$ per day indoors at or near their home [80]. Additionally, during the first trimester of pregnancy, exposure estimates based on residential address are strongly correlated with exposure estimates accounting for daily activities $(\mathrm{r}=0.98, p<0.01)$ [81].

\section{Conclusions}

In conclusion, we observed that API women residing in non-enclave areas have higher risk for GDM, regardless of VOC level. Residence in an ethnic enclave may mitigate the negative health effects of VOC exposure, potentially due to lower stress levels. Lower levels of stress among residents of ethnic enclaves may be related to greater access to culturally-relevant goods and services, and greater political representation $[3,4,15,24]$. API communities should lead culturally-relevant efforts to promote health through improved social and environmental conditions. Additional research is warranted to better understand the effects of joint exposures to air pollution and ethnic enclave across diverse ancestry groups within the broader U.S. API population.

\section{Abbreviations \\ 95\% Cl: 95\% confidence intervals; ACS: American Community Survey; API: Asian/Pacific Islander; BMI: Body mass index; CSL: Consortium on Safe Labor; GDM: Gestational diabetes mellitus; HRR: Hospital referral region; OR: Odds ratio; U.S.: United States; VOC: Volatile organic compounds; ZCTA: Zip code tabulation area}

\section{Supplementary Information}

The online version contains supplementary material available at https://doi. org/10.1186/s12940-021-00738-7.

\section{Additional file 1}

\section{Authors' contributions}

AW contributed to study design, conducted statistical analyses, interpreted the data, and wrote the first draft of the manuscript. LM, JK, SH, ES, and PM each contributed to the concept of the study, interpretation of the data, and provided extensive comments and critiques of the manuscript. All authors read and approved the final manuscript.

\section{Funding}

This research was supported by the Intramural Research Program of the National Institutes of Health, Eunice Kennedy Shriver National Institute of Child Health and Human Development (NICHD), including funding for the Consortium on Safe Labor (Contract No. HHSN267200603425C) and the Air Quality and Reproductive Health Study (Contract No. HHSN275200800002I, Task Order No. HHSN27500008). This paper has been cleared for publication by the NICHD but the funding source had no role in the design, analysis, interpretation or writing of the manuscript.

The ZIP code-HRR crosswalk data was obtained from The Dartmouth Atlas, which is funded by the Robert Wood Johnson Foundation and the Dartmouth Clinical and Translational Science Institute, under award number UL1TR001086 from the National Center for Advancing Translational Sciences (NCATS) of the National Institutes of Health (NIH).

Availability of data and materials

Consortium on Safe Labor data is publicly available at https://dash.nichd.nih. gov/. Geographic identifying information is not publicly available, please see 
http://grants.nih.gov/grants/policy/data_sharing/ for National Institutes of Health data sharing policy.

Dartmouth Atlas of Healthcare data is available at https://www.

darthmouthatlas.org/data

\section{Declarations}

\section{Ethics approval}

Institutional Review Boards at all study sites approved the CSL. The University of North Dakota Institutional Review Board waived need for approval.

\section{Competing interests}

No conflicts of interest to report.

\section{Author details}

${ }^{1}$ Public Health program, Department of Population Health, School of Medicine \& Health Sciences, University of North Dakota, Room E162, 1301 North Columbia Road Stop 9037, Grand Forks, ND 58202-9037, USA. ² School of Social Sciences, Humanities and Arts, Health Science Research Institute, University of California, 5200 N. Lake Road, Merced, CA, USA. ${ }^{3}$ Maternal and Child Health Program, Department of Family Science, University of Maryland College Park, 4200 Valley Drive, College Park, MD, USA. ${ }^{4}$ OHSU-PSU School of Public Health, Portland State University, 506 SW Mill Street 470H, Portland, OR, USA. ${ }^{5}$ Epidemiology Branch, Division of Intramural Population Health Research, Eunice Kennedy Shriver National Institute of Child Health and Human Development, 6710B Rockledge Drive, MSC, Bethesda, MD 7004, USA.

\section{Received: 25 August 2020 Accepted: 26 April 2021} Published online: 08 May 2021

\section{References}

1. Lopez G, Ruiz NG, Patten E. Key facts about Asian Americans, a diverse and growing population [Internet]. 2017. Available from: https://www.pewresea rch.org/fact-tank/2017/09/08/key-facts-about-asian-americans/

2. Bureau USC. Race and Hispanic or Latino: 2010 - United States -- Urban/ Rural and Inside/Outside Metropolitan and Micropolitan Area more information 2010 Census Summary File 1 [Internet]. 2011 [cited 2019 Mar 29]. Available from: https://factfinder.census.gov/faces/tableservices/jsf/pa ges/productview.xhtml?pid=DEC_10_SF1_GCTP3.US26\&prodType=table

3. Liu M, Geron K. Changing Neighborhood: Ethnic Enclaves and the Struggle for Social Justice [Internet]. Vol. 35, Social Justice. Social Justice/Global Options; 2008 [cited 2020 Mar 31]. p. 18-35. Available from: https://www. jstor.org/stable/29768486

4. Osypuk TL, Diez Roux AV, Hadley C, Kandula NR. Are immigrant enclaves healthy places to live? The multi-ethnic Study of atherosclerosis. Soc Sci Med. 2009:69(1):110-20. https://doi.org/10.1016/j.socscimed.2009.04.010.

5. Lim S, Yi SS, Lundy De La Cruz N, Trinh-Shevrin C. Defining Ethnic enclave and its associations with self-reported health outcomes among Asian American adults in New York City. J Immigr Minor Health. 2017;19(1):13846. https://doi.org/10.1007/s10903-015-0334-6.

6. Grineski SE, Collins TW, Morales DX. Asian Americans and disproportionate exposure to carcinogenic hazardous air pollutants: A national study. Soc Sci Med. 2017 Jul 1;185:71-80. https://doi.org/10.1016/j.socscimed.2017.05.042.

7. Sze J. Asian American activism for environmental justice. Peace Rev. 2004; 16(2):149-56. https://doi.org/10.1080/1040265042000237680.

8. Zou B, Peng F, Wan N, Mamady K, Wilson GJ. Spatial cluster detection of air pollution exposure inequities across the United States. PLoS One. 2014;9:3.

9. Yi SS, Kwon SC, Sacks R, Trinh-Shevrin C. Commentary: Persistence and health-related consequences of the model minority stereotype for Asian Americans [Internet]. Vol. 26, Ethnicity and Disease. ISHIB; 2016 [cited 2020 Aug 5]. p. 133-8. Available from: /pmc/articles/PMC4738850/?report= abstract.

10. Chou R, Feagin J. Myth of the model minority: Asian Americans facing racism. Boulder, CO: Paradigm Publishers; 2015. https://doi.org/10.4324/ 9781315636313

11. Williams AD, Messer LC, Kanner J, Ha S, Grantz KL, Mendola P. Ethnic enclaves and pregnancy and behavior outcomes among Asian/Pacific islanders in the USA. J Racial Ethn Heal Disparities. 2020;7(2):224-33. https:// doi.org/10.1007/s40615-019-00650-4.
12. Williams AD, Grantz KL, Zhang C, Nobles C, Sherman S, Mendola P. Ambient Volatile Organic Compounds and Racial/Ethnic Disparities in Gestational Diabetes Mellitus: Are Asian/Pacific Islander Women at Greater Risk? Am J Epidemiol [Internet]. 2019 [cited 2020 mar 31];188(2):389-397. Available from: http://www.ncbi.nlm.nih.gov/pubmed/30452528.

13. Von Behren J, Abrahão R, Goldberg D, Gomez SL, Setiawan W, Cheng I. The influence of neighborhood socioeconomic status and ethnic enclave on endometrial cancer mortality among Hispanics and Asian Americans/ Pacific islanders in California. Cancer Causes Control. 2018 Sep 1;29(9):87581. https://doi.org/10.1007/s10552-018-1063-7.

14. Glaser SL, Chang ET, Clarke CA, Keegan THM, Yang J, Gomez SL. Hodgkin lymphoma incidence in ethnic enclaves in California. Leuk Lymphoma. 2015 Dec 2;56(12):3270-80. https://doi.org/10.3109/10428194.2015.1026815.

15. Kane JB, Teitler JO, Reichman NE. Ethnic enclaves and birth outcomes of immigrants from India in a diverse U.S. state. Soc Sci Med. 2018;209:67-75. https://doi.org/10.1016/j.socscimed.2018.05.035.

16. Yang TC, Shoff C, Noah AJ, Black N, Sparks CS. Racial segregation and maternal smoking during pregnancy: Amultilevel analysis using the racial segregation interaction index. Soc Sci Med. 2014;107:26-36. https://doi. org/10.1016/j.socscimed.2014.01.030.

17. Pickett KE, Shaw RJ, Atkin K, Kiernan KE, Wilkinson RG. Ethnic density effects on maternal and infant health in the Millennium Cohort Study. Soc Sci Med [Internet]. 2009 [cited 2020 mar 31];69(10):1476-83. Available from: http:// www.ncbi.nlm.nih.gov/pubmed/19765872.

18. Janevic T, Borrell LN, Savitz DA, Echeverria SE, Rundle A. Ethnic enclaves and gestational diabetes among immigrant women in New York City. Soc Sci Med [Internet]. 2014 [cited 2020 mar 31];120:180-9. Available from: http:// www.ncbi.nlm.nih.gov/pubmed/25259656.

19. Shell AM, Peek MK, Eschbach K. Neighborhood Hispanic composition and depressive symptoms among Mexican-descent residents of Texas City. Texas Soc Sci Med. 2013;99:56-63. https://doi.org/10.1016/j.socscimed.2013.1 0.006 .

20. McClure HH, Josh Snodgrass J, Martinez CR, Squires EC, Jiménez RA, Isiordia $L E$, et al. Stress, place, and Allostatic load among Mexican immigrant farmworkers in Oregon. J Immigr Minor Health. 2015;17(5):1518-25. https:// doi.org/10.1007/s10903-014-0066-z.

21. McMurtry CL, Findling MG, Casey LS, Blendon RJ, Benson JM, Sayde JM, et al. Discrimination in the United States: experiences of Asian Americans. Health Serv Res. 2019;54(S2):1419-30. https://doi.org/10.1111/14756773.13225.

22. Paradies $Y$, Ben J, Denson N, Elias A, Priest N, Pieterse A, et al. Racism as a determinant of health: A systematic review and meta-analysis. PLoS One. 2015 Sep;23:10(9)

23. Walker RJ, Strom Williams J, Egede LE. Influence of race, ethnicity and social determinants of health on Diabetes outcomes. Am J Med Sci. 2016:351(4): 366-73. https://doi.org/10.1016/j.amjms.2016.01.008.

24. Zhou M, Cho M. Noneconomic effects of ethnic entrepreneurship: A focused look at the Chinese and Korean enclave economies in Los Angeles. Thunderbird Int Bus Rev [Internet]. 2010 Mar 1 [cited 2020 Mar 31];52(2):8396. Available from: http://doi.wiley.com/10.1002/tie.20316

25. Woodruff TJ, Parker JD, Kyle AD, Schoendorf KC. Disparities in Exposure to Air Pollution during Pregnancy [Internet]. Vol. 111, Environmental Health Perspectives. The National Institute of Environmental Health Sciences; 2003 [cited 2020 Aug 7]. p. 942-6. Available from: https://www.jstor.org/sta ble/3435169

26. van den Hooven EH, de Kluizenaar Y, Pierik FH, Hofman A, van Ratingen SW Zandveld PYJ, et al. Chronic Air Pollution Exposure during Pregnancy and Maternal and Fetal C-Reactive Protein Levels: The Generation R Study. Environ Health Perspect [Internet]. 2012 May [cited 2020 Mar 31];120(5):74651. Available from: https://ehp.niehs.nih.gov/doi/10.1289/ehp.1104345

27. Lee PC, Talbott EO, Roberts JM, Catov JM, Sharma RK, Ritz B. Particulate air pollution exposure and c-reactive protein during early pregnancy. Epidemiology. 2011 Jul;22(4):524-31. https://doi.org/10.1097/EDE.0b013e31 $821 c 6 c 58$.

28. Robledo CA, Mendola P, Yeung E, Männistö T, Sundaram R, Liu D, et al. Preconception and early pregnancy air pollution exposures and risk of gestational diabetes mellitus. Environ Res [Internet]. 2015 [cited 2020 mar 31];137:316-22. Available from: http://www.ncbi.nlm.nih.gov/pubmed/25601 734.

29. Lowe LP, Metzger BE, Lowe WL, Dyer AR, McDade TW, McIntyre HD. Inflammatory mediators and glucose in pregnancy: results from a subset of 
the hyperglycemia and adverse pregnancy outcome (HAPO) study. J Clin Endocrinol Metab. 2010;95(12):5427-34. https://doi.org/10.1210/jc.2010-1662

30. Gerber PA, Rutter GA. The Role of Oxidative Stress and Hypoxia in Pancreatic Beta-Cell Dysfunction in Diabetes Mellitus. Vol. 26, Antioxidants and Redox Signaling. Mary Ann Liebert Inc; 2017. p. 501-18.

31. Kaneto H, Kawamori D, Matsuoka TA, Kajimoto Y, Yamasaki Y. Oxidative stress and pancreatic $\beta$-cell dysfunction. In: American Journal of Therapeutics. Am J Ther; 2005. p. 529-33.

32. Bahadar H, Maqbool F, Mostafalou S, Baeeri M, Rahimifard M, Navaei-Nigjeh $M$, et al. Assessment of benzene induced oxidative impairment in rat isolated pancreatic islets and effect on insulin secretion. Environ Toxicol Pharmacol [Internet]. 2015 [cited 2018 Oct 24];39(3):1161-9. Available from: http://www.ncbi.nlm.nih.gov/pubmed/25935538.

33. Bhopal RS. A four-stage model explaining the higher risk of Type 2 diabetes mellitus in South Asians compared with European populations. Vol. 30, Diabetic Medicine. Diabet Med; 2013. p. 35-42.

34. Ramachandran A, Wan Ma RC, Snehalatha C. Diabetes in Asia. Vol. 375, The Lancet. Lancet; 2010. p. 408-418, 9712, DOI: https://doi.org/10.1016/S01406736(09)60937-5.

35. Dhabhar FS. Effects of stress on immune function: The good, the bad, and the beautiful [Internet]. Vol. 58, Immunologic Research. Humana Press Inc:; 2014 [cited 2020 Jul 17]. p. 193-210. Available from: https://link-springercom.ezproxylr.med.und.edu/article/10.1007/s12026-014-8517-0

36. Muralidharan S, Mandrekar P. Cellular stress response and innate immune signaling: integrating pathways in host defense and inflammation. J Leukoc Biol [Internet]. 2013 Dec [cited 2015 Nov 18];94(6):1167-84. Available from: http://www.pubmedcentral.nih.gov/articlerender.fcgi?artid=3828604\&tool= pmcentrez\&rendertype $=$ abstract

37. Lang AL, Beier Jl. Interaction of volatile organic compounds and underlying liver disease: A new paradigm for risk. Biol Chem [Internet]. 2018 Jun 20 [cited 2020 Jun 23];399(11):1237. Available from: /pmc/articles/PMC6181143/ ?report=abstract.

38. Camarinho R, Garcia P V., Choi H, Rodrigues AS. Overproduction of TNF-A and lung structural remodelling due to chronic exposure to volcanogenic air pollution. Chemosphere [Internet]. 2019 May 1 [cited 2020 Jun 30];222: 227-34. Available from: https://pubmed-ncbi-nlm-nih-gov.ezproxylr.med. und.edu/30708156/

39. Fonken LK, Xu X, Weil ZM, Chen G, Sun Q, Rajagopalan S, et al. Air pollution impairs cognition, provokes depressive-like behaviors and alters hippocampal cytokine expression and morphology. Mol Psychiatry [Internet]. 2011 Oct [cited 2020 Jun 30];16(10):987-95. Available from: https://pubmed-ncbi-nlm-nih-gov.ezproxylr.med.und.edu/21727897/

40. Yoshida T, Yoshioka Y, Fujimura M, Kayamuro H, Yamashita K, Higashisaka K, et al. Urban aerosols induce pro-inflammatory cytokine production in macrophages and cause airway inflammation in vivo. Biol Pharm Bull [Internet]. 2010 [cited 2020 Jun 30];33(5):780-3. Available from: https:// pubmed-ncbi-nlm-nih-gov.ezproxylr.med.und.edu/20460754/

41. Freitas Lima LC, Braga V de A, do Socorro de França Silva M, Cruz J de C, Sousa Santos SH, de Oliveira Monteiro MM, et al. Adipokines, diabetes and atherosclerosis: an inflammatory association. Front Physiol [Internet]. 2015 Jan [cited 2015 Nov 19];6:304. Available from: http://www.ncbi.nlm.nih.gov/ pubmed/26578976.

42. McEwen BS, Tucker P. Critical biological pathways for chronic psychosocial stress and research opportunities to advance the consideration of stress in chemical risk assessment. Am J Public Health [Internet]. 2011 Dec [cited 2015 Oct 23];101 Suppl:S131-9. Available from: http://www.pubmedcentral.nih.gov/a rticlerender.fcgi?artid=3222511\&tool=pmcentrez\&rendertype=abstract

43. Morello-Frosch R, Shenassa ED. The environmental "riskscape" and social inequality: implications for explaining maternal and child health disparities. Environ Health Perspect [Internet]. 2006 Aug [cited 2015 Mar 26];114(8): 1150-3. Available from: http://www.pubmedcentral.nih.gov/articlerender. fcgi?artid $=1551987 \&$ tool=pmcentrez\&rendertype $=$ abstract

44. DeSisto CL, Kim SY, Sharma AJ. Prevalence estimates of gestational diabetes mellitus in the United States, pregnancy risk assessment monitoring system (PRAMS), 20072010. Prev Chronic Dis. 2014;11. https://doi.org/10.5888/pcd11.130415.

45. Hedderson MM, Darbinian JA, Ferrara A. Disparities in the risk of gestational diabetes by race-ethnicity and country of birth. Paediatr Perinat Epidemiol. 2010 Sep;24(5):441-8. https://doi.org/10.1111/j.1365-3016.2010.01140.x

46. Hedderson M, Ehrlich S, Sridhar S, Darbinian J, Moore S, Ferrara A. Racial/ ethnic disparities in the prevalence of gestational diabetes mellitus by BMI. Diabetes Care. 2012 Jul;35(7):1492-8. https://doi.org/10.2337/dc11-2267.
47. Ferrara A. Increasing prevalence of gestational diabetes mellitus: a public health perspective. Diabetes Care. 2007;30(Suppl. 2):S141-6. https://doi.org/1 0.2337/dc07-s206.

48. Dabelea D, Snell-Bergeon JK, Hartsfield CL, Bischoff KJ, Hamman RF, McDuffie RS. Increasing prevalence of gestational diabetes mellitus (GDM) over time and by birth cohort: Kaiser Permanente of Colorado GDM screening program. Diabetes Care. 2005;28(3):579-84. https://doi.org/10.233 7/diacare.28.3.579.

49. Kim SY, England L, Sappenfield W, Wilson HG, Bish CL, Salihu HM, et al. Racial/ethnic differences in the percentage of gestational diabetes mellitus cases attributable to overweight and obesity, Florida, 2004-2007. Prev Chronic Dis. 2012;9:4.

50. Hunsberger M, Rosenberg KD, Donatelle RJ. Racial/ethnic disparities in gestational diabetes mellitus: findings from a population-based survey. Women's Heal Issues. 2010;20(5):323-8. https://doi.org/10.1016/j.whi.2010.06.003.

51. Savitz DA, Janevic TM, Engel SM, Kaufman JS, Herring AH. Ethnicity and gestational diabetes in New York City, 1995-2003. BJOG An Int J Obstet Gynaecol. 2008;115(8):969-78. https://doi.org/10.1111/j.1471-0528.2008.01 763.x.

52. Thorpe LE, Berger D, Ellis JA, Bettegowda VR, Brown G, Matte T, et al. Trends and racial/ethnic disparities in gestational diabetes among pregnant women in New York City, 1990-2001. Am J Public Health. 2005;95(9):1536-9. https://doi.org/10.2105/AJPH.2005.066100.

53. Committee on Practice Bulletins-Obstetrics. ACOG Practice Bulletin No. 190: Gestational Diabetes Mellitus. Obstet Gynecol [Internet]. 2018 Feb [cited 2020 mar 31];131(2):e49-64. Available from: http://www.ncbi.nlm.nih. gov/pubmed/29370047.

54. Dartmouth Institute for Health Policy \& Clinical Practice. Dartmouth Atlas of Health Care [Internet]. 2013 [cited 2017 Aug 1]. Available from: https://www. dartmouthatlas.org/

55. Zhang J, Troendle J, Reddy UM, Laughon SK, Branch DW, Burkman R, et al. Contemporary cesarean delivery practice in the United States. Am J Obstet Gynecol. 2010;203(4):326.e1-326.e10.

56. Gestational diabetes mellitus. Vol. 26, Diabetes Care. American Diabetes Association Inc; 2003. p. s103-5.

57. Chen G, Li J, Ying Q, Sherman S, Perkins N, Sundaram R, et al. Evaluation of observation-fused regional air quality model results for population air pollution exposure estimation. Sci Total Environ. 2014;485-486(1):563-74.

58. Williams AD, Wallace $M$, Nobles $C$, Mendola $P$. Racial residential segregation and racial disparities in stillbirth in the United States. Heal Place. 2018;51: 208-16. https://doi.org/10.1016/j.healthplace.2018.04.005.

59. Manson S, Schroeder J, Van Riper D, Ruggles S. IPUMS National Historical Geographic Information System: Version 12.0. 2016. Available from: https//umw.nhgis.org/

60. Allen JP, Turner E. Ethnic Residential Concentrations in United States Metropolitan Areas [Internet]. Vol. 95, Geographical Review. Taylor \& Francis, Ltd.; 2005 [cited 2020 Mar 31]. p. 267-85. Available from: https://www.jstor. org/stable/30033991

61. Massey DS, Denton NA. The dimensions of Residential segregation. Soc Forces. 1988 Dec 1;67(2):281-315. https://doi.org/10.2307/2579183.

62. Reardon SF, O'Sullivan D. 3. Measures of Spatial Segregation. Sociol Methodol [Internet]. 2004 Dec 24 [cited 2020 Mar 31];34(1):121-62. Available from: http://journals.sagepub.com/doi/10.1111/j.0081-1750.2004.00150.x

63. Cohen RA. Impact of Type of Insurance Plan on Access and Utilization of Health Care Services for Adults Aged 18-64 Years With Private Health Insurance: United States, 2007-2008 Key findings Data from the National Health Interview Survey [Internet]. 2007 [cited 2020 Mar 31]. Available from: https://www.cdc.gov/nchs/data/databriefs/db28.pdf

64. Semega J, Fontenot K, Kollar M. Income and Poverty in the United States: 2016. Curr Popul Reports; 2017. p. 60-259.

65. SAS Institute. SAS. Version 9.4. Cary, NC: SAS Institute Inc; 2014.

66. Thissen D, Steinberg L, Kuang D. Quick and Easy Implementation of the Benjamini-Hochberg Procedure for Controlling the False Positive Rate in Multiple Comparisons. J Educ Behav Stat [Internet]. 2002 Mar 23 [cited 2020 Jul 14];27(1):77-83. Available from: http://journals.sagepub.com/doi/10.31 02/10769986027001077, 27, 1, 77, 83

67. Pan SC, Huang CC, Lin SJ, Chen BY, Chang CC, Leon Guo YL. Gestational diabetes mellitus was related to ambient air pollutant nitric oxide during early gestation. Environ Res. 2017;158:318-23. https://doi.org/10.1016/j. envres.2017.06.005.

68. Pedersen M, Olsen SF, Halldorsson TI, Zhang C, Hjortebjerg D, Ketzel M, et al. Gestational diabetes mellitus and exposure to ambient air pollution 
and road traffic noise: A cohort study. Environ Int. 2017;108:253-60. https:// doi.org/10.1016/j.envint.2017.09.003.

69. Malmqvist E, Jakobsson K, Tinnerberg H, Rignell-Hydbom A, Rylander L. Gestational diabetes and preeclampsia in association with air pollution at levels below current air quality guidelines. Environ Health Perspect [Internet]. 2013 Apr [cited 2020 Apr 5];121(4):488-93. Available from: http:// www.ncbi.nlm.nih.gov/pubmed/23563048.

70. Shenassa ED, Williams AD. Concomitant exposure to area-level poverty, ambient air volatile organic compounds, and cardiometabolic dysfunction: a cross-sectional study of U.S. adolescents. Ann Epidemiol. 2020;48:15-22. https://doi.org/10.1016/j.annepidem.2020.05.014.

71. Kravitz-Wirtz N, Teixeira S, Hajat A, Woo B, Crowder K, Takeuchi D. Early-life air pollution exposure, neighborhood poverty, and childhood asthma in the United States, 1990-2014. Int J Environ Res Public Health. 2018;15:6.

72. Chan D. Sustainable communities for whom: cultural tactics in the pursuit of ecological sustainability. Asian am policy rev. 2018;28:52. Available from: https://search.proquest.com/docview/2188532832?.pq-origsite=gschola r\&fromopenview=true. Accessed 4 May 2021.

73. Eskeland Tarhan GSF. Rationing can backfire. World Bank Econ Rev [Internet]. 1997;11(3):383-408 Available from: https://elibrary.worldbank.org/ doi/abs/10.1093/wber/11.3.383.

74. Billingham C, Bluestone B, Pollack S. Maintaining diversity in America's transit-rich neighborhoods: tools for equitable neighborhood change. New Engl Community Dev [Internet]. 2010 [cited 2020 Aug 5];1-6. Available from: https://ideas.repec.org/a/fip/fedbcd/y2010p1-6n1.html

75. Quach T, Liu R, Nelson DO, Hurley S, Von Behren J, Hertz A, et al. Disaggregating data on Asian American and Pacific Islander women to provide new insights on potential exposures to hazardous air pollutants in California. Cancer Epidemiol Biomark Prev. 2014;23(11):2218-28. https://doi. org/10.1158/1055-9965.EPI-14-0468.

76. Osypuk TL. Invited commentary: integrating a life-course perspective and social theory to advance research on residential segregation and health. Am J Epidemiol [Internet]. 2013 [cited 2020 Apr 5];177(4):310-5. Available from: http://www.ncbi.nlm.nih.gov/pubmed/23337313.

77. Luecken DJ, Yarwood G, Hutzell WT. Multipollutant modeling of ozone, reactive nitrogen and HAPs across the continental US with CMAQ-CB6. Atmos Environ. 2019 Mar 15;201:62-72. https://doi.org/10.1016/j.atmosenv.2 018.11.060.

78. Bell ML, Belanger K. Review of research on residential mobility during pregnancy: Consequences for assessment of prenatal environmental exposures. Vol. 22, Journal of Exposure Science and Environmental Epidemiology: NIH Public Access; 2012. p. 429-38.

79. Chen L, Bell EM, Caton AR, Druschel CM, Lin S. Residential mobility during pregnancy and the potential for ambient air pollution exposure misclassification. Environ Res [Internet]. 2010 [cited 2020 Apr 5];110(2):162-8. Available from: http://www.ncbi.nlm.nih.gov/pubmed/19963212.

80. Nethery E, Brauer M, Janssen P. Time-activity patterns of pregnant women and changes during the course of pregnancy. J Expo Sci Environ Epidemiol [Internet]. 2009 Mar [cited 2020 Apr 5];19(3):317-24. Available from: http:// www.ncbi.n/m.nih.gov/pubmed/18478047.

81. Ouidir M, Giorgis-Allemand L, Lyon-Caen S, Morelli X, Cracowski C, Pontet S, et al. Estimation of exposure to atmospheric pollutants during pregnancy integrating space-time activity and indoor air levels: does it make a difference? Environ Int. 2015 Nov 1;84:161-73. https://doi.org/10.1016/j. envint.2015.07.021.

\section{Publisher's Note}

Springer Nature remains neutral with regard to jurisdictional claims in published maps and institutional affiliations.

Ready to submit your research? Choose BMC and benefit from:
- fast, convenient online submission
- thorough peer review by experienced researchers in your field
- rapid publication on acceptance
- support for research data, including large and complex data types
- gold Open Access which fosters wider collaboration and increased citations
- maximum visibility for your research: over 100M website views per year
At BMC, research is always in progress.
Learn more biomedcentral.com/submissions

